\title{
Mobile Banking: A Potential Catalyst for Financial Inclusion and Growth in Pakistan
}

\author{
Syed Kumail Abbas Rizvi*' Bushra Naqvi**and Fatima \\ Tanveer $^{* * *}$
}

\begin{abstract}
Almost half the world's adult population lacks access to a formal bank account and other financial services. Pakistan is no exception and it is also among those countries at the lower end of the spectrum of financial inclusion. However, steps are being taken by government regulators and the private sector to improve access to financial services such as credit, savings, remittances and insurance. The introduction of mobile banking is a notable step in this context. Mobile banking, which comprises mobile wallets and over-the-counter transactions, is rapidly growing around the world and has the potential to reduce barriers to financial inclusion and thus transform economies. The benefits of this platform are even more pronounced for economies with a weak financial architecture and where formal banking entails considerable costs in terms of time and distance. This paper traces the history of mobile banking in Pakistan, studies various models of mobile banking and assesses its current state using the available data to understand how this segment has evolved and transformed conventional banking structures in the country. It also touches on the ecosystem that needs to be built in Pakistan to utilize the full potential of mobile technology.
\end{abstract}

Keywords: Mobile banking, financial inclusion, branchless banking, Pakistan.

JEL classification: G21, G23, G28, O16.

\section{Introduction}

Financial inclusion is the process of ensuring the availability of, and access to, basic financial products and services. This includes credit facilities,

\footnotetext{
* Associate Professor, Lahore School of Economics, Pakistan.

** Assistant Professor, SDSB, Lahore University of Management Sciences, Pakistan.

*** Research Associate, Centre for Research in Economics and Business (CREB), Lahore School of Economics, Pakistan.
} 
savings, bank accounts and insurance services. If targeted at disadvantaged groups such as low-income and vulnerable households in a reasonable and transparent way, it can serve as a tool for social and economic development and poverty alleviation. On a larger scale, it can strengthen financial institutions, boost economic progress and reduce income inequality (Cull, Ehrbeck \& Holle, 2014).

Almost half the world's adult population (approximately 2.5 billion people) lacks access to a formal bank account and other financial services, with Pakistan being no exception. The Financial Inclusion Insights Survey for 2015 reports that approximately 93 percent of the adult population of Pakistan is financially excluded - barely 7 percent of respondents had a bank account - while listed accounts with other types of financial institutions are significantly low. ${ }^{1}$ However, financial inclusion figures are gradually improving. This improvement was recently acknowledged by Findex and the Access to Finance Survey. ${ }^{2}$ Findex shows an improvement in inclusion from 10 percent in 2011 to 13 percent in 2014; access to finance numbers have improved from 10 to 23 percent.

Despite these notable improvements, Pakistan's financial inclusion numbers still disappoint when compared to regional and global standards. In South Asia, Pakistan ranks lowest, with only 13 percent of adults having bank accounts relative to Sri Lanka (83 percent), India (53 percent), Nepal (34 percent), Bhutan (34 percent) and Bangladesh (31 percent). At a global level, financial inclusion is also low when compared to sub-Saharan Africa (34 percent), Latin America and the Caribbean (51 percent) and developing countries overall (51 percent) (Khan \& Rashid, 2015). Moreover, Pakistan falls below the international gender gap: more women are financially excluded than men. The disparity is also visible between rural and urban dwellers and their relative access to basic financial services.

Government regulators and the private sector have taken steps to improve access to financial services such as credit, savings, remittances and insurance, with mobile banking being the most important step. The mobile banking platform, which comprises mobile or m-wallets and over-the-

\footnotetext{
${ }^{1}$ http:/ / finclusion.org/

2 According to the Findex definition, financial inclusion means "having an account either by oneself or together with someone else, at a bank or another type of financial institution, or having personally used [mobile money] in the past 12 months." The Access to Finance Survey by the State Bank of Pakistan defines financial inclusion as those who are "formally served" within this sector.
} 
counter (OTC) transactions, has grown rapidly around the world and has the potential to reduce barriers to financial inclusion and thus transform economies (Klein \& Mayer, 2011). The benefits are even more pronounced for economies with a weak financial architecture and where formal banking entails considerable costs in terms of time and distance (Ghosh, 2016).

With mobile banking, conducting financial transactions - such as bill payments, money transfers and purchases - in a timely, secure and efficient manner becomes easier. This builds the aspiration toward a world in which everybody with a mobile phone, even those living in remote areas, can access and operate a full set of financial services. For the poor, it improves income and expense management and reduces their vulnerability to unforeseen events (Hughes \& Lonie, 2007; Johnson, 2014). Mobile penetration has also led to the emergence of branchless banking (BB) by minimizing the cost of transactions and bank branches. It contributes to economic growth through the channels of output growth, employment generation, productivity, reduced transaction costs, better functioning markets and financial inclusion, leading to poverty alleviation (Triki \& Faye, 2013).

In this paper, we aim to trace the history of mobile banking in Pakistan. We also study various models of mobile banking and assess its current state using the available data to understand how the segment has evolved and transformed conventional banking structures in the country. The paper also touches on the ecosystem that needs to be built in Pakistan to utilize the full potential of the mobile banking platform and to accelerate economic growth.

In what follows, Section 2 discusses the potential of mobile banking to increase financial inclusion and transform economies. Section 3 provides a structural overview of mobile banking in Pakistan. Section 4 documents the evolution of mobile banking from its inception in 2011. Section 5 analyzes the current state of the industry, its key players and growth in different segments of mobile banking. Section 6 describes the ecosystem needed to foster the growth of mobile banking to help policymakers achieve the broader goals of financial inclusion and economic development. Section 7 concludes the study.

\section{Mobile Banking and Financial Inclusion: Transforming Economies}

Several definitions of mobile banking exist, but all acknowledge the use of a cellphone to facilitate financial transactions (Porteous, 2007; 
Donner \& Escobari, 2010). Mobile phones give users access to a digital wallet, which can be used to conduct various transactions - transfer funds, check account balances, send and receive remittances, repay loans, generate receipts, pay bills and school fees and even save without the need for minimum account balances and heavy banking fees (see Jenkins, 2008; Aker \& Mbiti, 2010; McKinsey Global Institute, 2016; Hughes \& Lonie, 2007; Khan \& Rashid, 2015).

Access to mobile and digital devices has grown rapidly across the world. Mobile money applications have become popular in Asia, Africa and Latin America (Klein \& Mayer, 2011). For instance, the M-PESA mobile application in Kenya has enabled users to make transactions such as bill payments, money transfers and purchases, transforming a money transfer system to a platform that permits organizations, schools, hospitals and firms to send and receive payments (Hughes \& Lonie, 2007; Johnson, 2014).

With mobile banking, individuals can make bank transactions without having to visit a bank branch, which increases the efficacy of the account holder by saving time (Ahmed et al., 2011; Mishra \& Sahoo, 2013; Aker \& Mbiti, 2010). It is also an alternative to the traditional bank branch and ATM network through which most people, even those in remote areas, gain easier access to formal financial services (Siddik et al., 2014). The cost of transactions and running bank branches has been reduced with mobile penetration, leading to the emergence of BB (Ivatury \& Mas, 2008).

Some studies have identified a link between mobile money and economic growth through various channels, including increased output and employment creation (Lewin \& Sweet, 2005), better firm productivity (Donner \& Escobari, 2010), improved capital accumulation (Venturini, 2009), reduced transaction costs (Aker \& Mbiti, 2010), better functioning markets and financial inclusion. Mobile money drives the process of financial inclusion by improving the flow of information and providing cost-effective financial services to customers and unbanked clients (Andrianaivo \& Kpodar, 2012). This is a way of closing the financial infrastructure gap in emerging economies where formal banking entails considerable costs in terms of time and distance.

With the improved flow of information, the data collected on depositors facilitates the analysis of creditworthiness, credit allocation monitoring and deposit uptake. Mobile banking allows access to several market instruments and financial services at a lower cost for all income levels, which gives it the potential for affecting growth and development 
through productivity gains (Triki \& Faye, 2013). The mobile network also unlocks access to markets and services for numerous, generally lowincome, customers who would otherwise be financially excluded. Their inclusion within the financial system helps alleviate poverty by enabling people to acquire large sums of money to invest in income-generating activities, asset creation, and training and education (thus expanding their job market prospects).

Mobile banking also improves income and expense management and reduces vulnerability to unforeseen events such as accidents, illness, theft or drought, as people reduce their reliance on unsafe informal financial services and formal products they cannot afford (Jenkins, 2008). By improving the flow of information within networks, mobile banking also improves household risk sharing and awareness of income shocks (Aker \& Mbiti, 2010; Khan \& Rashid, 2015). These improvements in making the unbanked population a part of the formal financial system by improving their access to financial services can serve as a poverty eradication tool, foster inclusive growth and help countries meet the Millennium Development Goals (Chibba, 2009). Ghosh (2016) finds that mobile telephony in India has had a positive and significant impact on growth, financial inclusion and loan disbursement.

Greater mobile penetration boosts rural development, as it allows dispersed families to keep in touch. Better information flows via mobile phones reduce information asymmetries for farmers, improve their bargaining power and facilitate nonagricultural economic activities (Andrianaivo \& Kpodar, 2012). As more people enter the pool of formal finance, the mass of the financial sector grows, in turn enhancing economic growth (Levine, 2004).

Mobile banking also provides financial access to more women in developing economies. When women have access to financial accounts, they tend to increase expenditure on food, education and healthcare, which increases household wellbeing and productivity (Doepke \& Tertilt, 2011). For individuals, mobile banking improves the convenience, cost and range of available financial products. It boosts the capacity of loans granted to individuals and businesses and helps the government save billions every year by reducing leakages in spending and tax revenues (Khan \& Rashid, 2015). These savings can then be effectively utilized to increase expenditure on public investment in education, healthcare and infrastructure. 
Digital payments improve revenues by decreasing the extent of the informal economy and unregistered businesses that do not pay taxes or adhere to business regulations. This creates efficiency improvements and results in cost savings (McKinsey Global Institute, 2016). Moreover, mobile banking boosts the GDP by reducing the cost of transferring money, which leads to more remittances, capturing cash for savings and investments. This augments neighboring industries. For instance, mobile banking facilitates financial tools such as cash transfers, prepaid savings and credit, performance-based funding and micro-insurance. The benefits of the latter feed into the healthcare industry by facilitating access to affordable healthcare services. This, in turn, improves people's productivity, eventually increasing GDP (Gencer, 2011).

Increases in GDP may also be linked to the rise in productivity of businesses and governments using digital payment methods and from the supplementary investment that greater financial inclusion (of people and small businesses) brings. The remaining increase in GDP would be a result of the time saved by individuals that could be used for additional hours of work (McKinsey Global Institute, 2016). From a business point of view, mobile banking gives businesses the opportunity to improve services for existing customers and target new ones. In specific industries such as software, telecommunications and retail, it gives firms the chance to develop new business lines (Khan \& Rashid, 2015).

Overall, expanding access to finance through mobile money (mobile banking) not only increases financial inclusion, but also improves productivity and investment, reduces poverty, empowers women and helps strengthen institutions by making them more transparent. These benefits to individuals, businesses and governments can have a cumulative effect on growth in emerging economies.

\section{Overview of the Mobile Banking Industry in Pakistan}

Mobile banking or BB is an alternative to conventional banking and involves the use of technology to generate cheaper, alternative channels for conducting transactions. The State Bank of Pakistan (SBP)'s Branchless Banking Regulations address commercial banks, Islamic banks and microfinance banks under the domain of financial institutions. ${ }^{3}$ The bankled BB model holds the bank ultimately accountable, irrespective of whether other partners/agents have a regulatory stake in the bank. The regulations

${ }^{3}$ http:/ / www.sbp.org.pk/bprd/201 1/C9-Enclosure-2.pdf 
allow bank-agent relationships through joint ventures or agency arrangements. Table 1 outlines the BB models approved by the SBP.

Table 1: Permissible BB models in Pakistan

\begin{tabular}{|c|c|}
\hline Model & Description \\
\hline One-to-one (1-1) & $\begin{array}{l}\text { Permits a single bank to enter an agency agreement or } \\
\text { joint venture with one mobile network operator, } \\
\text { allowing improved customer service and product } \\
\text { innovation. }\end{array}$ \\
\hline One-to-many $(1-\infty)$ & $\begin{array}{l}\text { Permits a single bank to collaborate with various } \\
\text { mobile network operators to provide multiple financial } \\
\text { services over mobile phones, reaching a larger } \\
\text { clientele. However, this limits exclusivity in a } \\
\text { relationship and product innovation due to less } \\
\text { intricacy and coordination. }\end{array}$ \\
\hline Many-to-many $(\infty-\infty)$ & $\begin{array}{l}\text { Permits multiple banks and telecoms to offer joint } \\
\text { services to customers. This involves a third-party } \\
\text { service provider (usually a financial institution or its } \\
\text { subsidiary) that directs the flow of transactions. The } \\
\text { advantage is wider outreach, but coordination } \\
\text { becomes more difficult with so many players involved. }\end{array}$ \\
\hline
\end{tabular}

Source: Authors calculations

In addition, the SBP recognizes that any of the permissible models can be implemented and executed using one of two, or both, key channels (OTC and m-wallet) available to customers for BB services.

\subsection{OTC Channels}

OTC is the most widely used channel, through which the customer need visit the retailer offering BB services only once. This eliminates the need for a distinct account with any financial institution, mobile service provider or mobile network. Utility bill payments and domestic remittances are among the most common BB OTC services being offered and account for the majority market share.

Consumers can avail the services they need without having to enter a long-term contract with any service provider. The retailers who serve as intermediaries earn a commission on every transaction. They work under a prepaid model: the super-agent (the telecom company) provides cash deposit/withdrawal services to customers via their mobile phones, which 
differentiates it as a retailer, and/or installs a POS machine onsite, which eliminates the need to arrange cash at that end.

\subsection{Mobile Wallets}

The concept of a mobile wallet is that it provides banking services and account access to clients through their mobile phones and a reliable telecom connection. This reduces the customer's reliance on the retailer. Service providers benefit in the form of direct access to the customer and higher margins since they do not have to split commissions with retailers. Having a long-term relationship with the customer means that $s /$ he is less likely to switch providers. In return, the service provider offers better service and more innovative products.

While ATM cards with m-wallets have also been introduced to reduce reliance on retailers, ATMs are not all that widely distributed, especially in rural areas where many BB customers live. Commercial approval of m-wallets has been slow and is still less than expected, even though they offer financial inclusion to the unbanked.

\section{Evolution of Mobile Banking in Pakistan}

The initial achievements of mobile banking in Pakistan are due to the collective efforts of a diverse range of stakeholders. These include the government, regulatory bodies, development agencies, financial institutions, telecom operators and technology companies. As Figure 1 shows, mobile banking was initiated in 2005/06 when the SBP began discussions with international agencies to build its knowledge of international best practices. In 2006, the Consultative Group to Assist the Poor (CGAP) carried out a BB diagnostic assessment of Pakistan to develop an understanding of the regulatory environment linked to BB. Following this, a seminar on improving access to financial services - titled 'mobile money transfer and beyond' - was arranged by the SBP and Asian Development Bank to share information and experiences of technology models such as mobile money transfer. 

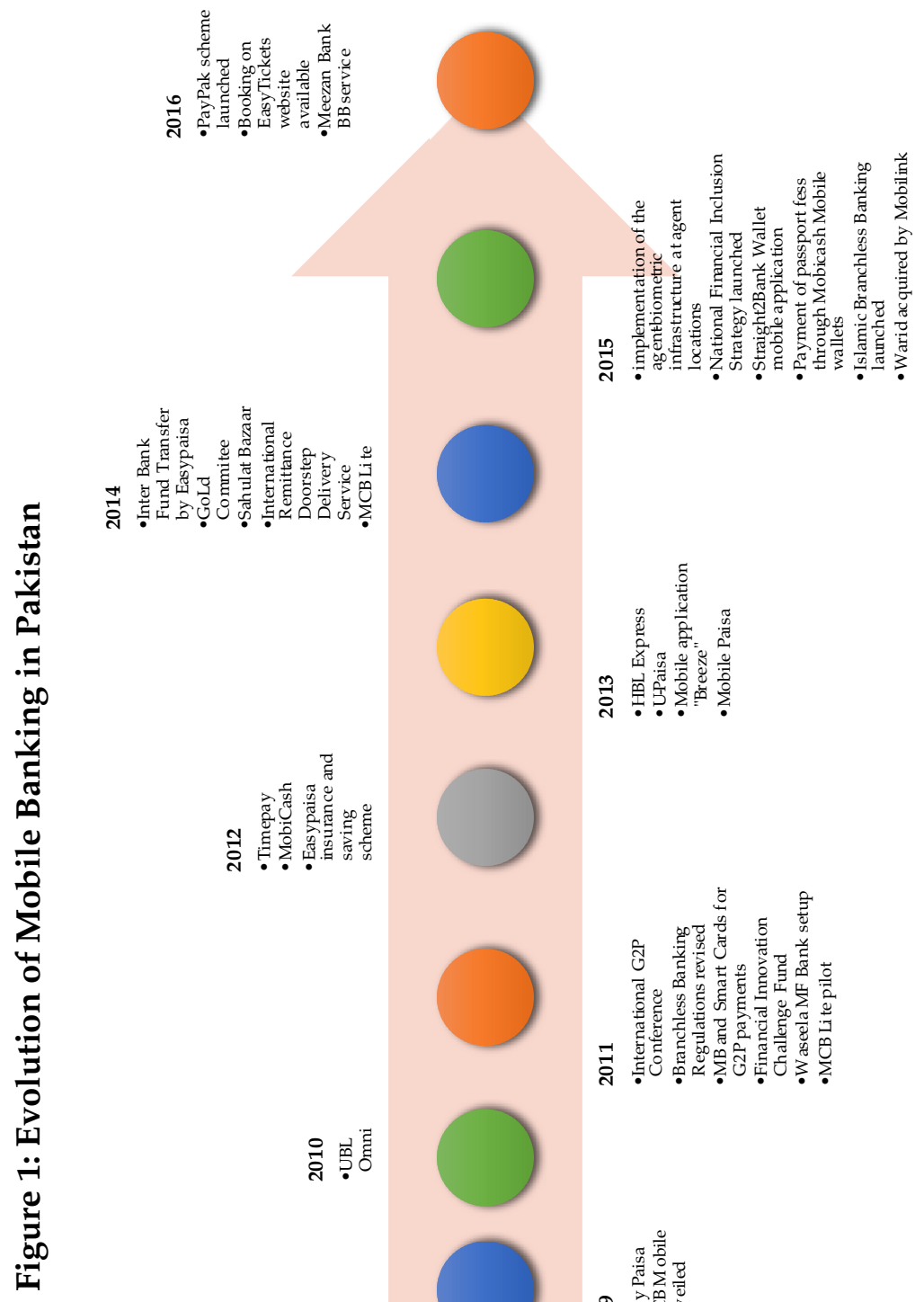

ํ.?
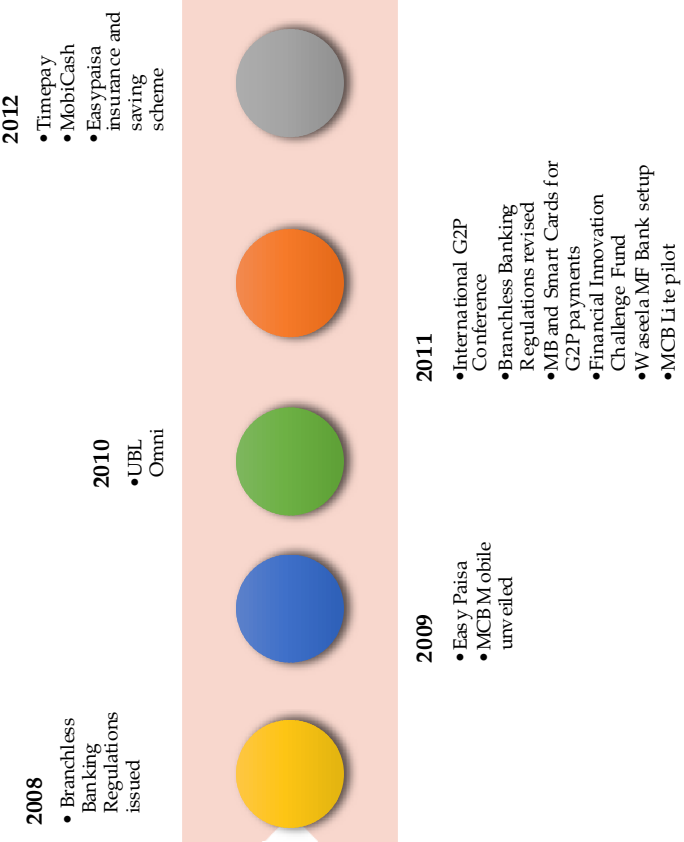

究
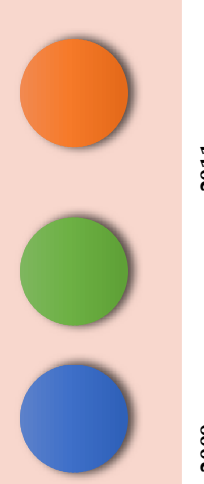

สิ

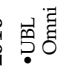
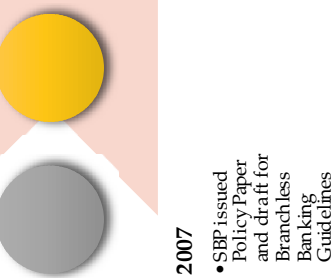
In 2007, under its Expanding Microfinance Outreach strategy, the SBP agreed to draft a set of BB regulations to aid profitmaking and to help microfinance banks boost their outreach via this technology. It then issued a policy paper highlighting the regulatory framework for mobile banking and a set of draft BB guidelines for stakeholders. The Branchless Banking Regulations were issued and adopted by the SBP in 2008 and revised in 2011 to allow a structural approach to know-your-customer (KYC) requirements, which made Pakistan the first country to have issued these regulations. The regulations encouraged partnership models, both one-toone and one-to-many.

The first such partnership was Easypaisa, which was launched in 2009 as a one-to-one joint venture between Telenor Pakistan and Tameer Microfinance Bank. The SBP also licensed United Bank Limited (UBL) to start its pilot BB product, UBL Omni, which was formally launched in 2010 as a direct agent-based BB model. In July 2009, MCB Bank became the first bank in Pakistan to unveil a mobile financial service, MCB Mobile.

In 2010, the SBP announced a strategic framework for sustainable microfinance that reiterated its support for transformational BB to encourage financial inclusion in Pakistan. Government efforts to promote novelty and technology in banking culminated in an international government-to-person (G2P) conference held in May 2011. Policymakers and analysts debated the dynamics of BB and Pakistan's performance in this context: the country was portrayed as an upcoming market with visible market development. Subsequently, the government introduced G2P payments - such as cash transfers under the Benazir Income Support Program and payments to flood-affected households - through mobile phones and smart cards. Tameer Microfinance Bank signed an agreement with the Employees OldAge Benefits Institution (EOBI) to make pension payments through Easypaisa to hundreds of pensioners registered with the latter.

In 2011, the Financial Innovation Challenge Fund was launched under the British-funded Financial Inclusion Program (FIP) by the former governor of the SBP. This was followed by the initial round of G2P payments. Worth GBP10 million, the fund was aimed at providing grants to encourage innovations and assess new markets, reduce the cost of service delivery, help systems and procedures become more effective and offer innovative ways of addressing the unmet demand for financial services. Further pilot BB products were rolled out by MCB (MCB Lite) and Askari Bank. Waseela Microfinance Bank was set up after Orascom, the country's largest mobile network operator, received a license to do so. 
The Nationwide Financial Literacy Program was launched in 2012 by the SBP in collaboration with the Asian Development Bank. This was aimed at conducting financial workshops and introducing low-income Pakistanis to the concept of savings, investment and BB across the country. The SBP signed an MOU with the Pakistan Telecommunication Authority (PTA) to collaborate on procedural and regulatory matters related to BB. There was also tremendous growth in the BB industry in the same year, with two more entrants. Askari Bank and Zong jointly launched Timepey, a BB solution. Waseela Microfinance Bank partnered with Mobilink to launch MobiCash, a portfolio comprising services such as utility bill payment, money transfers, cash deposits and withdrawals. To enhance the use of BB services, Easypaisa launched an insurance and savings scheme for account holders in the third quarter of 2012.

HBL became the fifth player in the BB sector after launching a oneto-many BB model, HBL Express, in April 2013. It also joined hands with NADRA Technologies under the Branchless Banking Super Agency Agreement as a planned association, enabling more than 5,500 NADRA eSahulat outlets to offer BB financial transactions under HBL Express. In August, U Microfinance Bank commenced UPaisa BB operations in partnership with Ufone with an extensive network of about 90,000 agents. It also partnered with EFU Life to provide insurance products and services to customers, and with Southern Sui Gas Company to enable customers to make online payments at thousands of UPaisa payment points.

Warid Telecom signed an MOU with Meezan Bank and Monet, following which it rolled out a Warid Telecom payment gateway for Meezan Bank's BB services, with Monet serving as their technology partner. Standard Chartered Bank launched a mobile banking application under the brand name 'Breeze', making Pakistan the second market in the MEPA region where this application is used. U Microfinance Bank signed an MOU with the National Bank of Pakistan (NBP) to offer private and corporate solutions through BB services to NBP customers across Pakistan. Warid Telecom, in collaboration with Bank Alfalah, launched a mobile financial service named Mobile Paisa in the last quarter of 2013.

In 2014 an MOU was signed between the Bank of Punjab, Zong and Inov8 to publicize their partnership for digitizing government flows through BB. Easypaisa became inter-operable with the banking structure by introducing an inter-bank funds transfer service that allowed its customers to transfer funds across various bank branches through 1LINK. It also launched two innovative products, the Gold Committee and Sahulat Bazaar, 
in partnership with ARY Digital. Easypaisa has played an active role in the education sector, having signed an agreement with the Sindh Education Reform Program to manage the distribution of stipends to empower girls and fight poverty.

Other events during the year included an international BB conference organized by the SBP, during which it signed an MOU with NADRA to reduce the cost of biometric variation to PKR10 for m-wallet applications at the industrial level. A second MOU was signed between the Gates Foundation and DfID to set up a digital financial inclusion unit at Karandaaz, a recently incorporated company that nurtures small and developing businesses in Pakistan.

In October, the SBP organized a two-day in-house training session in conjunction with CGAP to provide SBP officials with a knowledge platform on international perceptions and practices in $\mathrm{BB}$, particularly on payment efficacy, regulatory background, payment mechanisms and standards, and inter-operability. Other highlights included the Easypaisa launch of an international remittance doorstep delivery service, an MOU between the NBP and Ufone for payments and reimbursements under the Prime Minister's Youth Business Loan scheme, and an agreement signed by MobiCash to make payments on behalf of the Pakistan Bait-ul-Mal Child Support Program.

In 2015, the implementation of an agent biometric infrastructure at agent locations was begun, primarily by Easypaisa and MobiCash, to promote financial inclusion. The federal finance minister formally launched the National Financial Inclusion Strategy (NFIS) in May, which aims to introduce reforms for enhancing financial inclusion prospects in a sustained manner. Several notable partnerships emerged: between HBL and NADRA for launching BB services, between Karandaaz and the Bank of Punjab for digitizing government transactions, and between Easypaisa and Standard Chartered Bank for a corporate mobile payment service, Straight2Bank Wallet.

The NBP, the Directorate General of Immigration and Passports and MobiCash signed an MOU for the payment of passport fees at MobiCash outlets and through MobiCash m-wallets. Batwa and Wavetec collaborated with MobiCash to become the first mobile company to launch near-field communication payments through vending machines for some 1.5 million mobile account holders. Finally, the world's first Islamic BB service was inaugurated and Warid was acquired by Mobilink. 
Key developments in 2016 included the launch of PayPak, a domestic payments scheme, and EasyTickets, a website enabling customers to book cinema tickets online. The SBP and PTA signed an MOU for developing a regulatory framework for mobile banking interoperability. Meezan Bank emerged as a new player in the sector and Bank Alfalah's BB offered computerized salary disbursements for corporate companies and EOBI pension disbursements and collection.

\section{Current State of Mobile Banking in Pakistan}

This section provides an overview of the industry and its key players. It also looks at the evolution of different key performance indicators in mobile banking.

\subsection{Industry Players}

As mentioned earlier, although players in this sector follow a bankled model, the inclusion of multiple partners - particularly technology partners - has meant that they focus on brand development rather than projecting the original identities of one or more partners. Table 2 outlines the characteristics of each brand being operated in the mobile banking sector. 


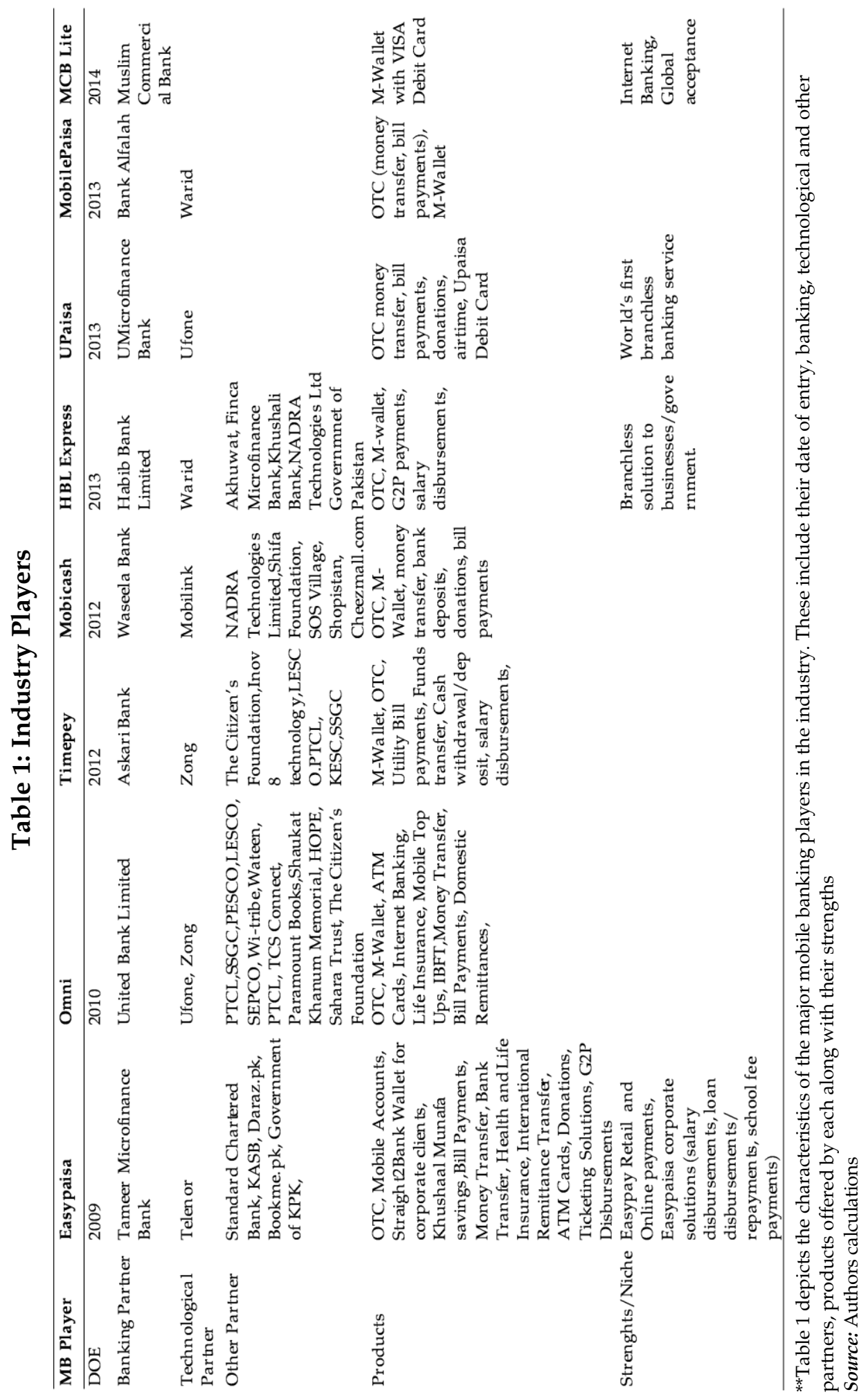


Among these players, MobiCash dominates the category of active accounts with a 48 percent share, followed by competitors such as Easypaisa (28 percent) and Omni (23 percent). The remaining brands have negligible market shares in this group. Easypaisa leads with 33 percent of active agents, followed by MobiCash (24 percent), Upaisa (16 percent) and Omni (13 percent). Mobile Paisa, Meezan Upaisa, HBL Express, Timepey and $\mathrm{MCB}$ Lite account for the remaining active agents (less than 10 percent). Easypaisa, MobiCash and Omni have the highest market shares in terms of transaction value and volume (Figure 2).

Figure 2: Market shares of brands

Market Share (Brands)

Active Accounts

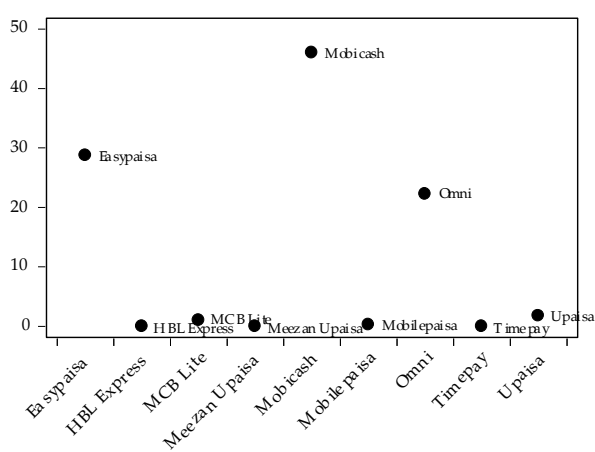

Transaction Volume

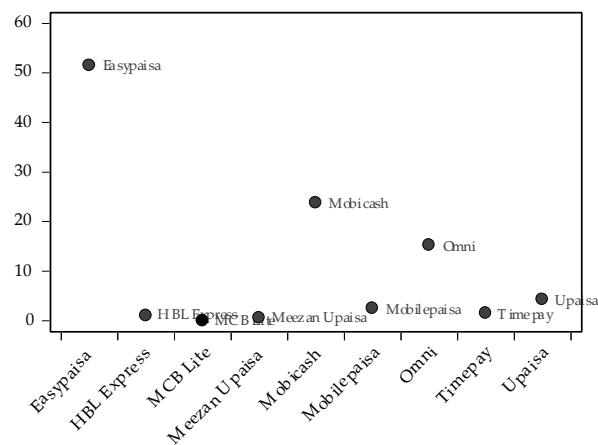

Active Agents

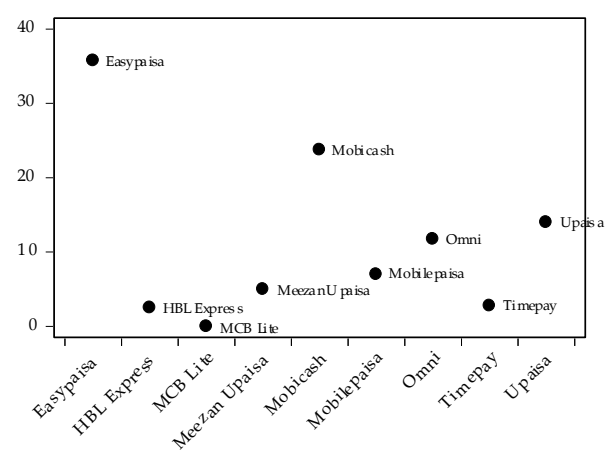

Transaction Volume

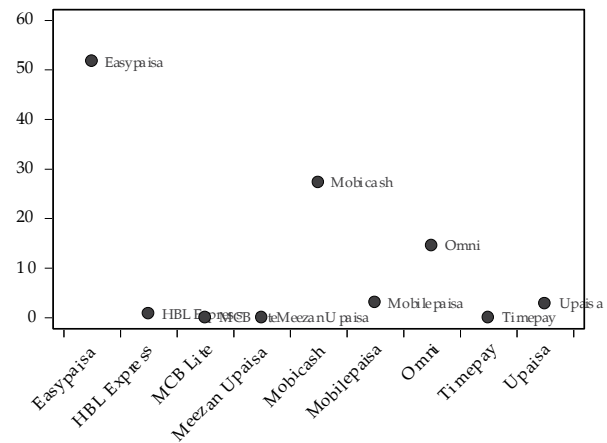

Source: Authors calculations

It is interesting to see which banks are behind the most successful brands. Based on the share of each bank, Waseela Microfinance Bank has the highest percentage ( 48 percent) of active accounts, followed by Tameer Microfinance Bank (28 percent), UBL (22 percent) and U Microfinance Bank. The strength of the OTC network can be gauged from the network 
of active agents. Tameer leads with a 36 percent share of all active agents, followed by Waseela, U Microfinance and UBL. Alfalah, Meezan Bank and others account for the remaining share (Figure 3). In terms of the value and volume of transactions, Tameer accounts for more than half the market, followed by Waseela and UBL. U Microfinance, Alfalah and others occupy a very small share.

\section{Figure 3: Market shares of banks}

\section{Market Share (Banks)}
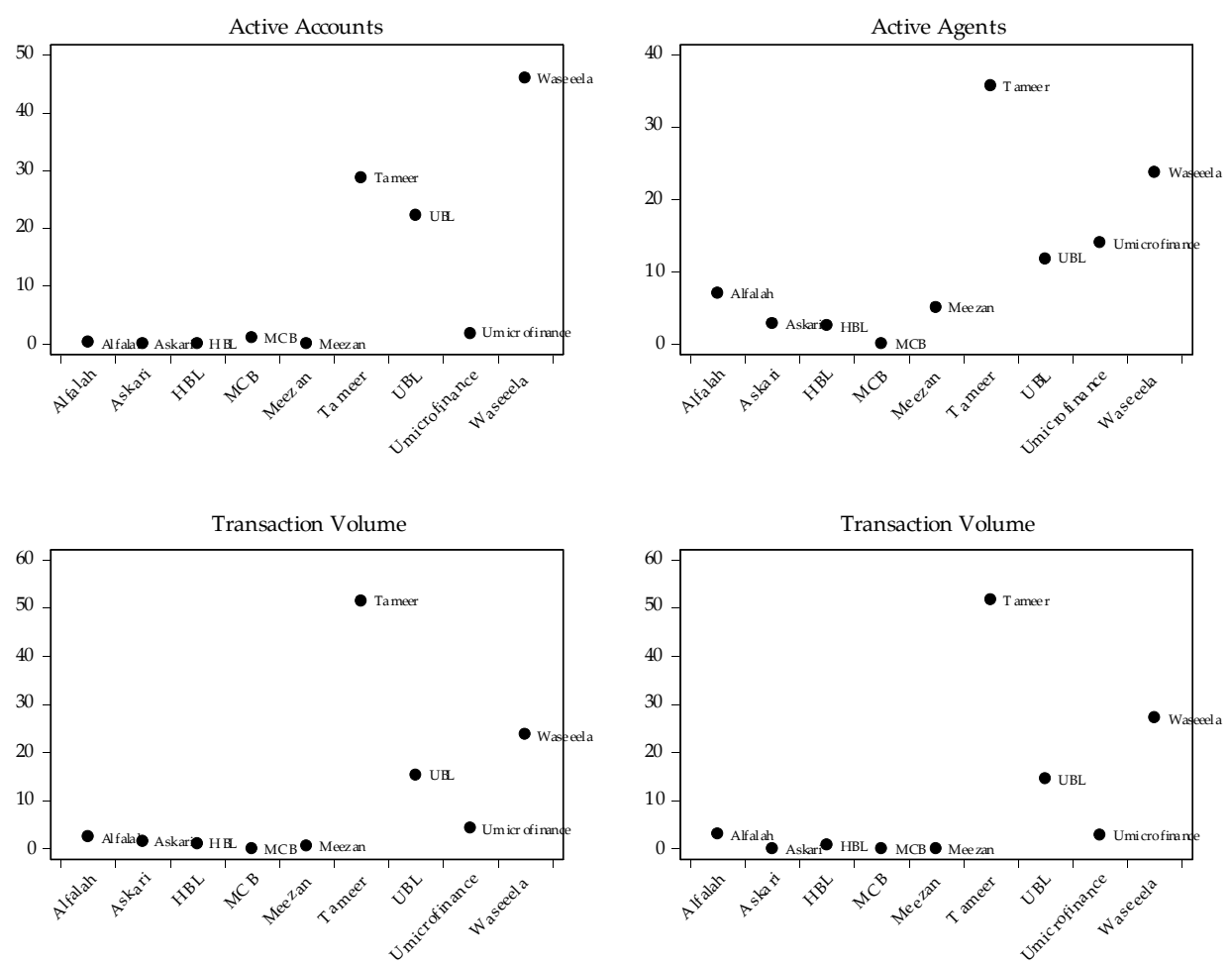

Source: Authors calculations

Figure 4 illustrates the share of each mobile network operator or telecom partner. Mobilink, Waseela Bank's technology partner, manages MobiCash and has the most active accounts, followed by Telenor and the joint venture between Ufone and Zong (Omni). In terms of active agents, Telenor has the highest share, followed by Mobilink and Ufone/Zong. Telenor accounts for more than half the market in terms of the value and volume of transactions, followed by Mobilink (about 25 percent) and 
Ufone/Zong (Omni). Other technology partners such as Warid, Zong and Ufone (independently) have a very small share of the market.

\section{Figure 4: Market shares of mobile network operators}

Market Share (Mobile Operators)
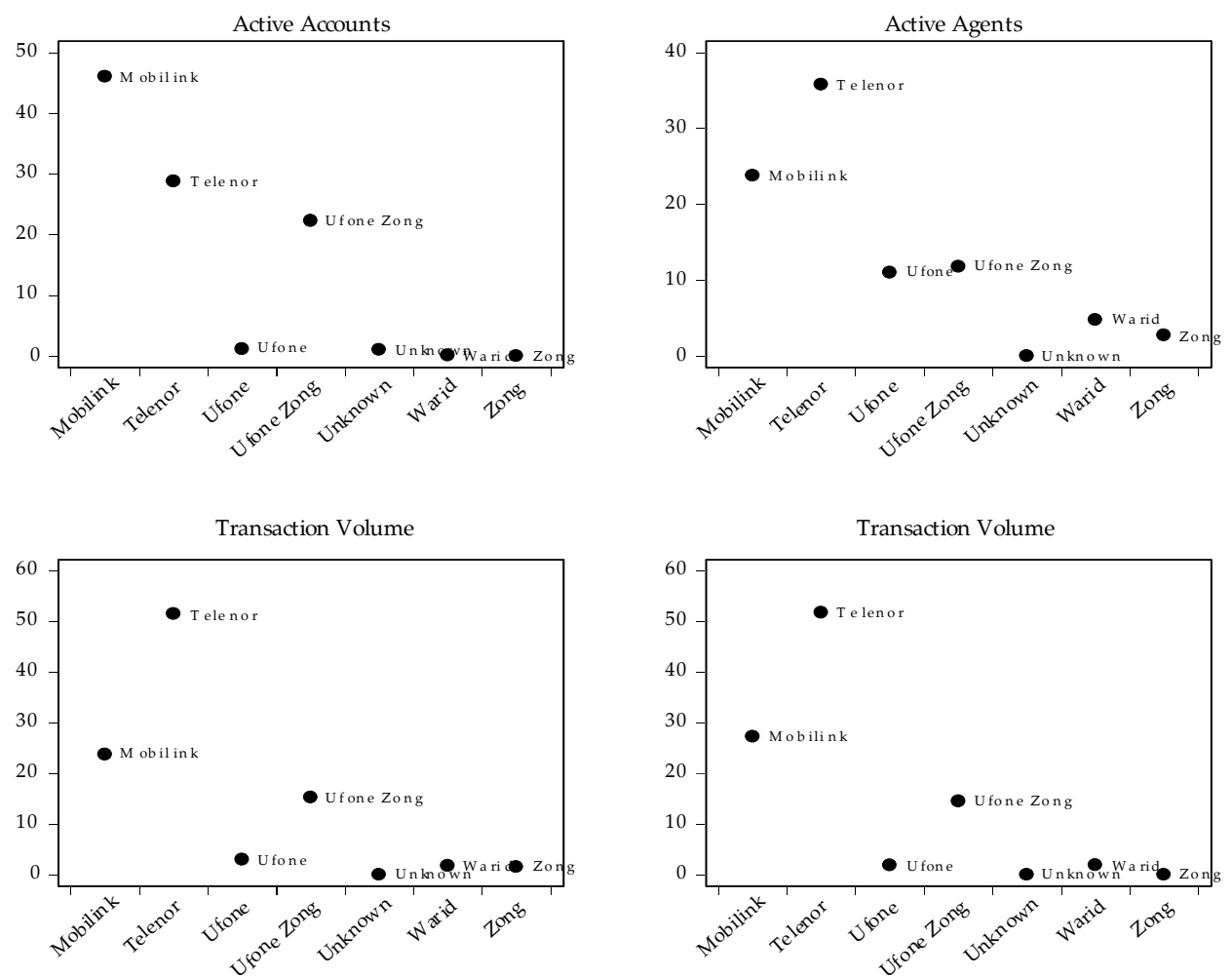

Source: Authors calculations

\subsection{How Big is the Market?}

Figure 5 illustrates the evolution and size of the mobile banking market at the end of the second quarter of 2016 (the latest data available at the time of writing). The number of mobile banking transactions shows an increasing trend during 2011-16. Starting from 15 million transactions in the third quarter of 2011, the number has risen over time with slight fluctuations in the last quarter of 2014, when the growth of this sector remained almost stagnant. However, immediately after this pause, the second quarter of 2015 saw a noticeable increase in the volume of transactions, nearing 100 million in this quarter compared to the previous one (73 million). The following quarters witnessed persistent growth, reaching 118.7 million transactions in 
2016. As with volume, the value of transactions has also increased over time, with some dips in the third quarters of 2013, 2014 and 2015, after which it reached PKR543.6 billion in 2016.

Figure 5: Growth trends: Value and volume of BB transactions

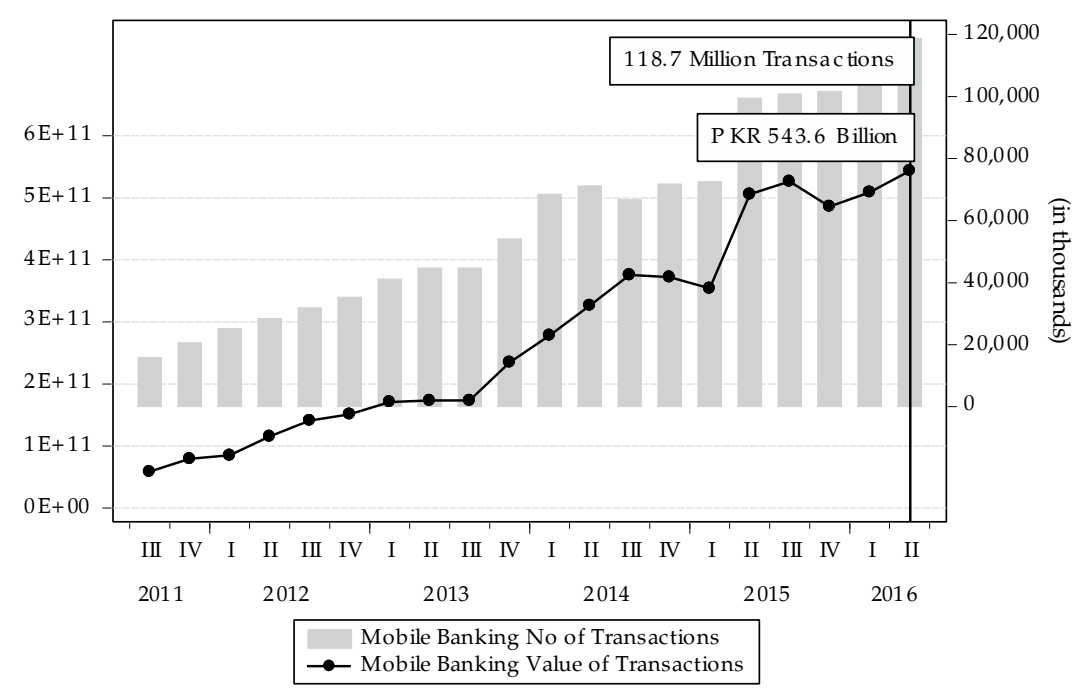

Source: Authors calculations

Figure 6 illustrates differential performance based on the annualized growth rate of several BB variables. The number of mobile banking (BB) accounts has grown at an annual rate of around 114.3 percent since 2011. The growth rate of active agents and agents is 45.1 and 99.2 percent, respectively. The number of transactions per day has a growth rate of 50.8 percent, although the average transaction size has grown more slowly at 6.9 percent annually. Deposits have grown, on average, by 130 percent annually over the last five years. The value of transactions reveals a reasonable growth rate of 61.9 percent, indicating users' adaptability and their confidence in conducting higher-value transactions using a mobile platform.

Next, we analyze the nature and flow of transfers made by mobile banking users through OTC or m-wallet channels. Figures 7 and 8 illustrate the volume and growth rates of different types of transfers made by mobile banking users. Of these, agent-to-agent, person-to-person (P2P) and bankto-agent transfers dominate in terms of volume, although they have grown fairly slowly. Agent-to-agent transfers have grown by 16 percent, bank-to- 
agent transfers by 10 percent and P2P transfers by 7.7 percent per quarter. Agent-to-bank transfers have the lowest growth rate (2.5 percent).

Figure 6: Average yearly growth rates, BB variables

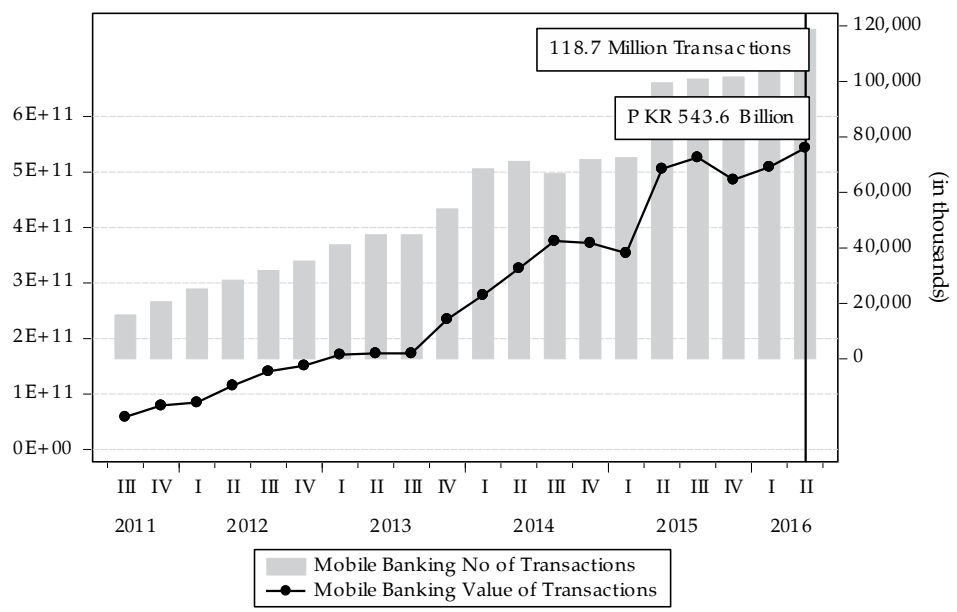

Source: Authors calculations

Figure 7: Average volume of different types of transfers (in millions)

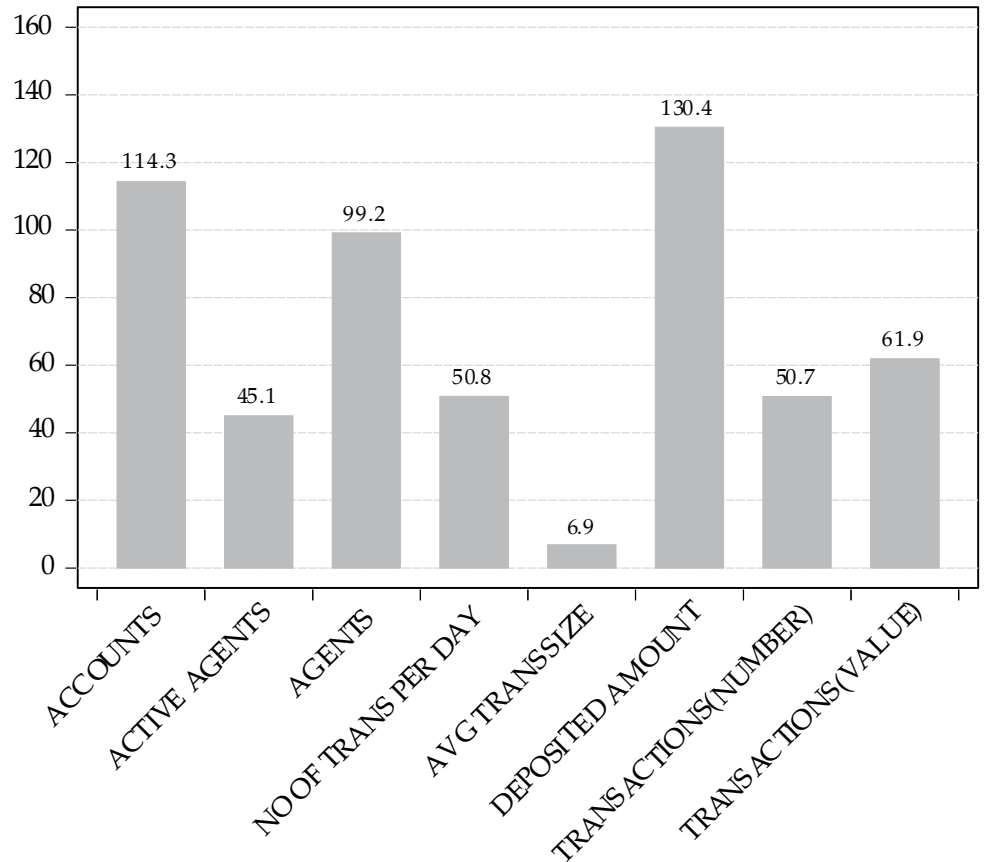

Source: Authors calculations 
Figure 8: Average quarterly growth rate of different types of transfers

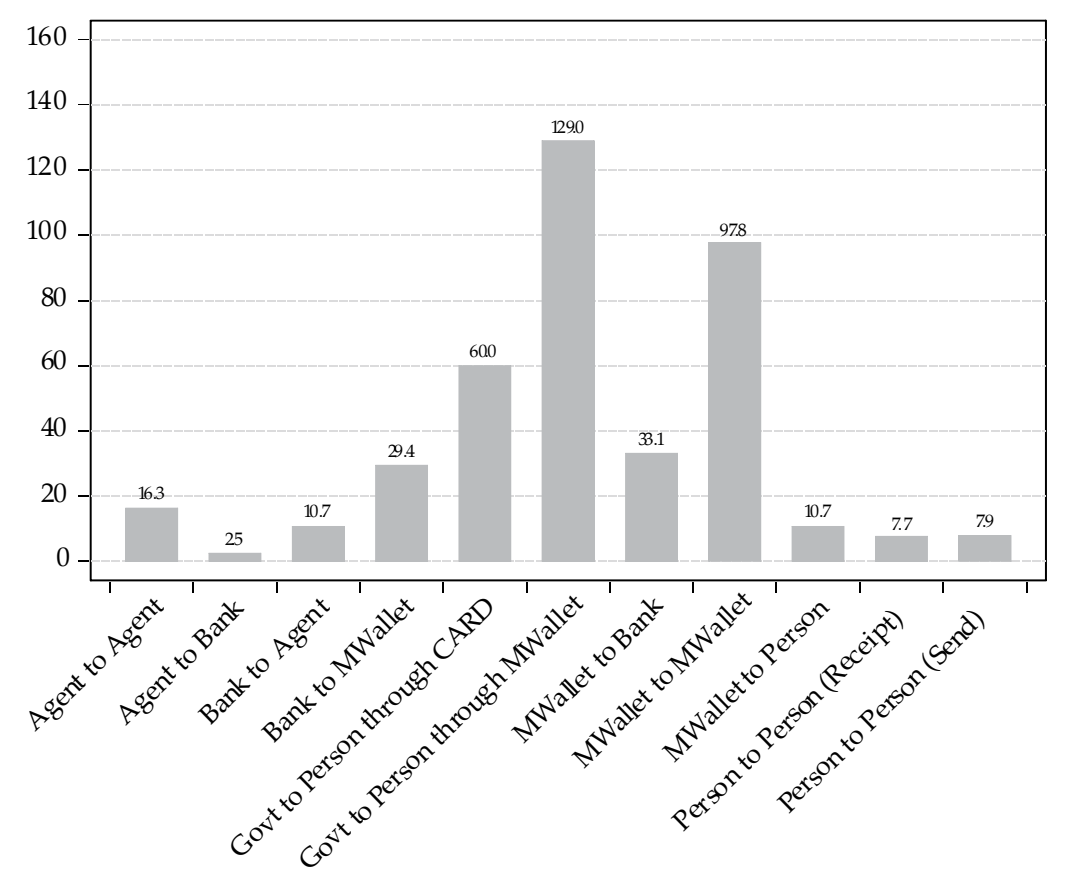

Source: Authors calculations

M-wallet transfers, an emerging component of mobile banking, have remained weak in terms of volume, but displayed impressive growth over time. Bank-to-m-wallet and m-wallet-to-bank transfers have the lowest volumes, but have shown reasonable growth rates of 29.4 percent and 31 percent, respectively. M-wallet-to-m-wallet transactions account for PKR3,790 million on average, which translates into a very high average growth rate of 97.8 percent per quarter. For G2P transfers, cards are more commonly used than $\mathrm{m}$-wallets, although their respective growth rates show the opposite. G2P transfers by m-wallet have grown rapidly by 120 percent per quarter, which is almost double the growth rate of G2P transfers by card.

Another important dimension is the difference between the use of OTC and m-wallet transfers to disburse and repay loans. Figure 9 shows that mobile banking platforms are not used extensively to disburse loans, as the volume and value of such transactions is nominal. On the other hand, loans are commonly repaid through BB, accounting for PKR1.8 billion on average and more than half a million transactions $(578,684)$ every 
quarter. This underlines the increasing popularity and acceptability of this market segment.

Figure 9: Loan disbursement and repayment transactions in Pakistan
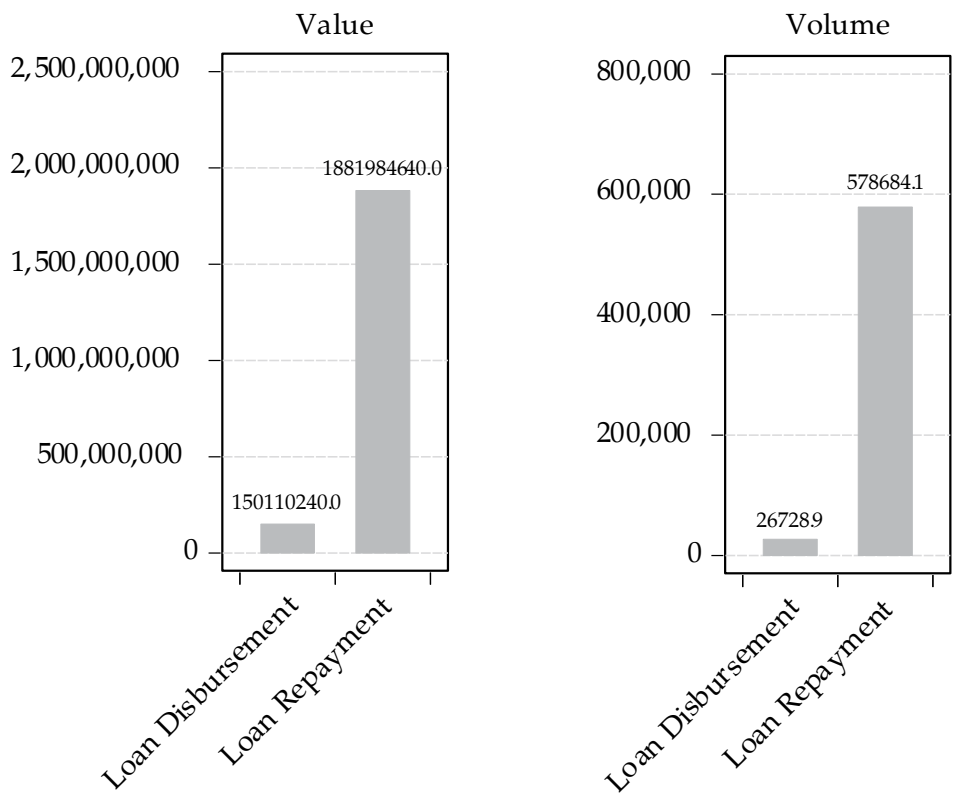

Source: Authors calculations

\section{What Kind of Ecosystem Helps Mobile Banking Thrive?}

Despite the evident success of mobile banking in Pakistan, there are several inherent constraints to the existing regulatory and financial structure that could limit the sector's growth. First, the limited range of permissible models are all bank-led. This needs to be expanded to allow other entities, primarily telecom companies, to play a greater role in the industry. What regulators must not ignore is that the sector is heavily dominated by agents that operate primarily under telecom companies. The latter need to be allowed - and given incentive - to become more prominent players rather than merely technical service providers on banks' behalf.

Second, innovation in this industry must be encouraged. So far, the industry has restricted itself to the provision of payment solutions - that too, on a partial basis. There is considerable room to expand in this and other areas. G2P transactions, for instance, have enormous potential. Transfers under the Benazir Income Support Program and payments to pensioners through mobile accounts are clear success stories. 
Third - and most important - is the large disparity in the share of mobile banking between loan disbursements and loan repayments (see Figure 9). The low penetration of mobile banking platforms in loan disbursements signals that commercial and microfinance banks still prefer the traditional banking practice of borrowers applying for loans in person at a physical bank branch, providing documents for the assessment of credit risk and putting up collateral to mitigate the chances of fraud. On the other hand, the frequent and significant use of mobile banking to make loan repayments highlights its potential to augment financial inclusion using low-cost mobile technology and to improve access to financial products and services. Mobile banking also aids the inclusion of people who might otherwise lack access to financial services, especially in rural areas.

\section{Box 1: Mobile banking: from 'cake to cash'}

From an early age, I was interested in culinary arts - especially baking. I enjoyed baking cakes and cupcakes for friends and family, who encouraged me to start a home-based bakery. Starting with occasional orders, I moved onto learning new cake-decorating techniques and recipes. My friends and family were very supportive of the idea and helped me at every step, from designing a brand logo, name and menu to having customized boxes made. That was when Sugar ' $n$ ' Spice, my home-baking venture, formally started. I used social media such as Facebook and Instagram to promote the business and boost orders.

While it has become common for people to order customized cakes to celebrate occasions, no profession is without its hiccups. These can range from late pickups and deliveries to the difficulty of catering last-minute orders and customers who refuse to collect their orders. Mobile banking services such as Easypaisa and MobiCash have facilitated the business, enabling me to receive advance payments from clients outside Lahore who want cakes made and delivered in the city. These safe and easy modes of payment allow me to receive payment confirmation text messages from clients, after which I can collect the cash from the nearest agent at local shops.

Despite having no professional diploma in culinary arts, my desire to learn and love of baking has always produced a great deal of positive energy and enabled me to grow and improve as a baker. My only worry is that I might accidently delete an Easypaisa confirmation message from my smartphone and be unable to collect payment!

Source: Fatima Tanveer (researcher and entrepreneur) 
In addition to these three constraints, which are specific to mobile banking, there are other barriers to inclusion at the macro level - these need persistent government support to facilitate greater financial inclusion. For example, there is still great disparity among the groups of people that are financially included. While the international gender gap in access to bank accounts has fallen to 7 percent in recent years, Pakistan lags behind with a gender gap of approximately 11 percent (World Bank, 2014). Above all, financial inclusion figures show that women are still more financially excluded than men: only 7 percent of women have a bank account relative to 23 percent of men (Khan \& Rashid, 2015).

The absence of a saving culture in Pakistan is another barrier to financial inclusion. Savings have risen, but most sources remain informal: more than half the cash saved is kept at home (51 percent) or with committees (27 percent) and only 3 percent of savings are deposited in a bank or microfinance institution. Pakistan's formal savings rate is the lowest among countries such as Kenya (30 percent), India (14 percent) and Bangladesh (7 percent). Moreover, there is scant awareness of insurance in Pakistan: the Financial Inclusion Insights Survey for 2013 shows that only 1 percent of people have insurance, the bulk of which is life insurance. The remainder are unaware of what insurance is or how to acquire it or feel they do not need it.

While the low savings rate is still a constraint to financial inclusion, domestic money transfers remain popular in Pakistan in comparison to peer countries such as India and Bangladesh. About 24.8 percent of people send remittances to friends and family, compared to 9.8 percent in India and 14.1 percent in Bangladesh. Most people (93 percent) rely on personal delivery, only 4 percent deposit this money directly into a bank and 3 percent use agent mobile money accounts to make transfers. Formal financial service use remains low due to unstable incomes, insufficient money to open an account and unawareness of products and services.

Given these macro-constraints, the SBP has implemented vital modifications to strengthen the financial system and increase financial inclusion. Issuing licenses to new private banks, initiatives to encourage the development of the microfinance sector, revolutionizing the governance and monitoring frameworks of the banking sector and capitalizing in a commercial bank for women are among the most visible steps taken.

The SBP has developed the FIP in conjunction with the UK Department for International Development (DfID) to address the lack of 
access to banking for a large share of Pakistan's population. Moreover, with support from the World Bank, it has developed a comprehensive NFIS to improve access to financial services such as credit, savings, remittances and insurance. However, to increase financial inclusion, the FIP and NFIS must be implemented more rigorously and persistently to overcome macroeconomic constraints such as the gender gap, low savings rate and prevalence of informal money transfers.

\section{Conclusion}

Mobile banking serves as a potential mechanism for stimulating financial inclusion, given the widespread penetration of mobile telephony and the viability of connecting data in a secure and economical way. The use of mobile phones connected to banking products aids the expansion of business models offering financial services to people who would otherwise have been excluded from the formal financial system. In addition, mobile penetration contributes to economic growth through the channels of output growth, employment generation, improved productivity, lower transaction costs, better functioning markets and financial inclusion leading to poverty alleviation.

Mobile banking in Pakistan began in 2005/06 when the SBP decided to initiate the concept. A key step was the preparation and adoption of the Branchless Banking Regulations in 2008. These were revised in 2011 to allow a structural approach to KYC requirements, which made Pakistan the first country to have issued such regulations. The BB regulations encouraged a range of partnership models. The first such partnership, Easypaisa, was launched in 2009. Since then, significant developments have occurred in mobile banking in Pakistan, including the recent launch of the NFIS and Straight2Bank wallet mobile application.

In recent years, the number of mobile banking transactions has risen. From 15 million transactions in 2011Q3, the number has increased to 118.7 million transactions in 2016. The value of such transactions has also increased, reaching PKR543.6 billion in 2016. The annualized growth rate of multiple $\mathrm{BB}$ variables indicates the progress of the sector. The number of mobile banking (BB) accounts has grown at an annual rate of around 114.3 percent since 2011. The growth rate of active agents and agents is 45.1 and 99.2 percent, respectively. The number of transactions per day has a growth rate of 50.8 percent, although the average transaction size has grown more slowly at 6.9 percent a year. Deposits have grown, on average, by 130 percent per annum consecutively for the last five years. The value 
of transactions has a reasonable growth rate of 61.9 percent, indicating users' adaptability and their confidence in conducting higher-value transactions using a mobile platform.

Despite the success of mobile banking in Pakistan, several aspects of the existing regulatory and financial structure could limit the sector's growth. First, the limited number of permissible models are all bank-led. Second, the industry has restricted itself to the provision of payment solutions and thus lacks innovation. Third - and most important - is the large disparity between the share of mobile banking in loan disbursement and loan repayments. The low penetration of mobile banking in loan disbursement signals that commercial and microfinance banks still prefer the traditional banking practice of borrowers applying for loans at a physical bank branch.

In addition, Pakistan falls below the international gender gap in terms of the groups of people that are financially included: women are still more financially excluded than men and there is still considerable disparity between rural and urban dwellers in terms of access to basic financial services. Finally, the culture of low savings and informal money transfers also poses challenges to financial inclusion. Nonetheless, these barriers provide a significant opportunity for regulators and policymakers to improvise and improve financial inclusion in Pakistan, given its projected role in economic growth. 


\section{References}

Ahmed, S. M. S., Rayhan, S. J., Islam, M. A., \& Mahjabin, S. (2011). Problems and prospects of mobile banking in Bangladesh. Journal of Information Engineering and Applications, 1(6), 16-35.

Aker, J. C., \& Mbiti, I. M. (2010). Mobile phones and economic development in Africa. Journal of Economic Perspectives, 24(3), 207-232.

Andrianaivo, M., \& Kpodar, K. (2012). Mobile phones, financial inclusion, and growth. Review of Economics and Institutions, 3(2), 1-30.

Chibba, M. (2009). Financial inclusion, poverty reduction and the Millennium Development Goals. European Journal of Development Research, 21(2), 213-230.

Cull, R., Ehrbeck, T., \& Holle, N. (2014). Financial inclusion and development: Recent impact evidence (Focus Note No. 92). Washington, DC: CGAP.

Doepke, M., \& Tertilt, M. (2011). Does female empowerment promote economic development? (Discussion Paper No. 8441). London: Centre for Economic Policy Research.

Donner, J., \& Escobari, M. X. (2010). A review of evidence on mobile use by micro and small enterprises in developing countries. Journal of International Development, 22(5), 641-658.

Gencer, M. (2011). The mobile money movement: Catalyst to jumpstart emerging markets. Innovations: Technology, Governance, Globalization, 6(1), 101-117.

Ghosh, S. (2016). How important is mobile telephony for economic growth? Evidence from MENA countries. info, 18(3), 58-79.

Hughes, N., \& Lonie, S. (2007). M-PESA: Mobile money for the 'unbanked': Turning cellphones into 24-hour tellers in Kenya. Innovations: Technology, Governance, Globalization, 2(1-2), 63-81.

Ivatury, G., \& Mas, I. (2008). The early experience with branchless banking (Focus Note No. 46). Washington, DC: CGAP.

Jenkins, B. (2008). Developing mobile money ecosystems. Washington, DC: International Finance Corporation and Harvard Kennedy School. 
Johnson, S. (2014). Competing visions of financial inclusion in Kenya: The rift revealed by mobile money transfer (Bath Papers in International Development and Wellbeing No. 30). Bath: University of Bath, Centre for Development Studies.

Khan, I., \& Rashid, N. (2015). Using mobile money to promote financial inclusion in Pakistan. PowerPoint presentation to Karandaaz, Islamabad. Retrieved from https://www.karandaaz.com.pk/wpcontent/uploads/2017/02/Using-Mobile-Money-to-PromoteFinancial-Inclusion-in-Pakistan.pdf

Klein, M., \& Mayer, C. (2011). Mobile banking and financial inclusion: The regulatory lessons (Policy Research Working Paper No. 5664). Washington, DC: World Bank.

Levine, R. (2004). Finance and growth: Theory and evidence (Working Paper No. 10766). Cambridge, MA: National Bureau of Economic Research.

Lewin, D., \& Sweet, S. (2005). The economic impact of mobile services in Latin America: A report for the GSMA, GSM Latin America and AHCIET. London: Indepen and Ovum.

McKinsey Global Institute. (2016). Digital finance for all: Powering inclusive growth in emerging economies. New York: McKinsey \& Company.

Mishra, S. K., \& Sahoo, D. P. (2013). Mobile banking adoption and benefits towards customers' service. International Journal on Advanced Computer Theory and Engineering, 2(1), 78-83.

Porteous, D. (2007). Just how transformational is m-banking? Johannesburg: FinMark Trust.

Siddik, N. A., Sun, G., Yanjuan, C. I. U, \& Kabiraj, S. (2014). Financial inclusion through mobile banking: A case of Bangladesh. Journal of Applied Finance and Banking, 4(6), 109-136.

Triki, T., \& Faye, I. (2013). Financial inclusion in Africa. Tunis: African Development Bank.

Venturini, F. (2009). The long-run impact of ICT. Empirical Economics, 37(3), 497-515.

World Bank. (2014). Global financial development report 2014: Financial inclusion. Washington, DC: Author. 


\section{Appendix}

\section{Milestones in the mobile banking industry, 2016/17}

\begin{tabular}{|c|c|c|}
\hline & Event & Details \\
\hline 1 & $\begin{array}{l}\text { Easypaisa partners } \\
\text { with EFU Life to } \\
\text { collect insurance } \\
\text { premiums }\end{array}$ & $\begin{array}{l}\text { With its countrywide network of about } 77,000 \text { agents, } \\
\text { Easypaisa will facilitate premium collection for EFU. } \\
\text { This partnership will support inter-operability to } \\
\text { enhance financial inclusion. }\end{array}$ \\
\hline 2 & $\begin{array}{l}\text { JazzCash and } \\
\text { Karandaaz enter a } \\
\text { strategic partnership } \\
\text { for digital financial } \\
\text { inclusion }\end{array}$ & $\begin{array}{l}\text { Karandaaz will provide financial and technical } \\
\text { support to JazzCash in implementing key findings of } \\
\text { the human-centered design research study recently } \\
\text { completed by the former. This will help JazzCash } \\
\text { innovate its existing mobile application and increase } \\
\text { its uptake among over } 50 \text { million Mobilink-Warid } \\
\text { customers. }\end{array}$ \\
\hline 3 & $\begin{array}{l}\text { JazzCash partners with } \\
\text { Tranglo to enable } \\
\text { international money } \\
\text { transfers }\end{array}$ & $\begin{array}{l}\text { Tranglo is a global cross-border digital remittance } \\
\text { hub. This partnership enables JazzCash users to } \\
\text { transfer money internationally using Tranglo's global } \\
\text { network. }\end{array}$ \\
\hline 4 & $\begin{array}{l}\text { Easypaisa app allows } \\
\text { new users to register } \\
\text { for an Easypaisa } \\
\text { account regardless of } \\
\text { their mobile operator }\end{array}$ & $\begin{array}{l}\text { Customers register using their mobile number and } \\
\text { CNIC, upon which a one-time password (OTP) is sent } \\
\text { to their phone and fed into the app automatically. } \\
\text { They enter the desired PIN and use it to login to the } \\
\text { application. Users can transfer money to any other } \\
\text { CNIC holder, bank account or Easypaisa account. } \\
\text { They can also pay utility bills and buy any operator's } \\
\text { airtime. }\end{array}$ \\
\hline 5 & $\begin{array}{l}\text { Easypaisa introduces } \\
\text { money transfer to any } \\
\text { mobile number }\end{array}$ & $\begin{array}{l}\text { Easypaisa users dial *786\# and select the money } \\
\text { transfer option. They choose the 'send to any mobile' } \\
\text { option and enter the receiver's mobile number and } \\
\text { transfer amount, followed by their Easypaisa account } \\
\text { PIN to complete the transaction. If the receiver doesn't } \\
\text { have an Easypaisa account, the money transfer } \\
\text { notification will prompt them to open one and receive } \\
\text { payments in that account instantly. }\end{array}$ \\
\hline 6 & $\begin{array}{l}\text { Tameer Microfinance } \\
\text { Bank partners with the } \\
\text { Punjab government to } \\
\text { disburse digital } \\
\text { interest-free loans }\end{array}$ & $\begin{array}{l}\text { This partnership entails the disbursal of smart digital } \\
\text { loans to over } 35,000 \text { farmers across Punjab, worth over } \\
\text { PKR } 2 \text { billion. The total scheme announced by the } \\
\text { Punjab government is worth over PKR } 77 \text { billion and } \\
\text { targets } 450,000 \text { farmers. This is intended to strengthen } \\
\text { the agricultural sector by increasing overall yield and } \\
\text { crop productivity. }\end{array}$ \\
\hline
\end{tabular}




\begin{tabular}{ll}
\hline & Event \\
\hline 7 & $\begin{array}{l}\text { JazzCash and Visa } \\
\text { introduce Visa debit } \\
\text { cards }\end{array}$ \\
$8 \quad$ JazzCash forms a \\
strategic alliance with \\
the Access Group
\end{tabular}

9 Easypaisa offers an affordable, accessible car insurance policy

JazzCash is a collaborative platform launched by Mobilink and Mobilink Microfinance Bank. In partnership with Visa, a global payments technology company, JazzCash will offer Visa debit cards to consumers. JazzCash mobile account customers will be able to make purchases at more than 50,000 retail outlets in Pakistan and from all online merchants that accept Visa and millions of merchants in more than 200 countries worldwide. This will also enable JazzCash to introduce loyalty offers for its customers by building alliances with key merchants.

This partnership will promote nationwide retail payment acceptance. One such innovative payment method to be introduced under this agreement is JazzCash's recently launched near-field communication payment solution.

10 Easypaisa introduces a money transfer facility using biometric verification devices

In collaboration with United Insurance Company, Easypaisa has introduced the industry's first car insurance scheme.

Easypaisa has introduced a biometric money transfer facility across its extensive network of retailers in Pakistan. Using biometric services, customers can avail advances of up to PKR50,000 and transfer higher amounts. Customers who do not wish to share their CNIC details will now be able to use this mobile financial service.

11 Easypaisa and JS Bank enter a strategic

alliance on BB

12 Easypay becomes the exclusive payment partner for Giftpoint.pk

In collaboration with Giftpoint.pk (a product of fintech company Inov8), Easypaisa will enable users to purchase gift cards either through their Easypaisa account or Visa/MasterCard credit/debit card, or by paying any of 75,000 Easypaisa agents across Pakistan.

13 JazzCash facilitates Kaymu customers

This partnership enables customers to pay for transactions on Kaymu using any debit/credit card, JazzCash mobile account or voucher from the nearest JazzCash outlet. 
Event

14 Easypaisa introduces a convenient school fee payment solution

15 Easypaisa launches Pakistan's first mobile credit line

16 Telenor Easy Shops and Daraz.pk partner to promote ecommerce across Pakistan

17 JazzCash launches health insurance with an annual cover of up to PKR50,000

18 Cinepax acquires a one-touch solution offer for ticket purchases with JazzCash

19 Meezan Bank honored

20 Easypaisa enables users to open an Easypaisa mobile account with any mobile operator SIM

\section{Details}

With Easypay, Easypaisa enables parents and students to pay online with the convenience of choosing a payment option that suits their needs. Users logon to the institution's website and provide their roll number, against which the system will automatically retrieve the amount payable. They can choose to pay via their Easypaisa account or any Visa or MasterCard credit/debit card or pay at any of the 75,000 Easypaisa agents across Pakistan.

This offers a term deposit with attractive returns and a credit facility with an instant approval bundle for Easypaisa account users. The deposit product offers a 10 percent return on savings with a monthly profit payout. These are among the best terms available among any banks in the country. Customers can avail a credit line at the cheapest possible rates without having to break their deposit.

Telenor will promote Daraz.pk, a leading e-commerce website, through Telenor Easy Shops.

Sehat Sahulat is an affordable health insurance service offered in partnership with TPL direct insurance to JazzCash mobile account customers. The service covers emergencies and inpatient hospitalization.

Moviegoers can buy tickets online at the Cinepax website or through the mobile app and pay using their JazzCash account.

Meezan Bank was named 'Innovator in Islamic Finance 2016' by Global Finance magazine for accelerating financial inclusion through Meezan UPaisa.

Easypaisa has introduced 'other mobile operator' interoperability through SMS-based transactions for feature phone users and a smartphone app for smartphone users. This means that anyone regardless of their operator SIM - can open an Easypaisa mobile account and operate it using a channel of their choice, including apps, SMS, USSD or phone banking. 


\begin{tabular}{lll}
\hline \multicolumn{1}{c}{ Event } & \multicolumn{1}{c}{ Details } \\
\hline 21 & $\begin{array}{l}\text { MobiCash becomes } \\
\text { JazzCash }\end{array}$ & Mobilink replaces its MobiCash brand with JazzCash. \\
22 & $\begin{array}{l}\text { SBP and PTA sign an } \\
\text { MOU for developing a } \\
\text { regulatory framework } \\
\text { for mobile banking }\end{array}$ & $\begin{array}{l}\text { This will formalize cooperation between the two } \\
\text { institutions in this area. }\end{array}$ \\
23 & $\begin{array}{l}\text { Easypaisa upgrades to } \\
\text { a next-generation } \\
\text { financial services } \\
\text { platform }\end{array}$ & $\begin{array}{l}\text { Easypaisa has upgraded to a next-generation financial } \\
\text { services platform established by technology provider }\end{array}$ \\
& $\begin{array}{l}\text { Ericsson. The new platform's open application } \\
\text { programming interface protocol will enable quicker } \\
\text { product development and pricing, thus providing } \\
\text { enhanced service quality. }\end{array}$ \\
24 & $\begin{array}{l}\text { Waseela Microfinance } \\
\text { Bank employs a TPS } \\
\text { IRIS payment switch }\end{array}$ & $\begin{array}{l}\text { This entails a next-generation enterprise switch and } \\
\text { financial middleware for ATM, POS and debit cards } \\
\text { with an IRIS end-to-end prepaid card solution. }\end{array}$ \\
\hline
\end{tabular}

Source: Authors calculations 